\title{
A lowermost Ordovician tabulate-like coralomorph from the Precordillera of western Argentina: a main component of a reef-framework consortium
}

\author{
Marcelo G. Carrera, Ricardo A. Astini and Fernando J. Gomez \\ CICTERRA-CONICET, Facultad Cs Exactas Físicas y Naturales, Universidad Nacional de Córdoba, Córdoba (X5016GCA), Argentina \\ 〈mcarrera@unc.edu.ar〉,〈ricardo.astini@unc.edu.ar〉,〈fjgomez@unc.edu.ar〉
}

\begin{abstract}
Although putative corals of uncertain affinities occur in the early Cambrian, the earliest definite tabulate corals have not been described prior to the Early Ordovician in North America. This paper reports a new finding of a tabulate-like coralomorph forming part of biostratigraphically well-constrained reef mounds in the latest Cambrian-Early Ordovician La Silla Formation in the Argentine Precordillera. The oldest record of the coralomorph genus Amsassia is reported and a new species, A. argentina, is erected. The discovery of this genus in the lowermost Ordovician modifies the previously proposed paleogeographic distribution and patterns of origination and migration routes of this coral-like organism. Amsassia argentina n. sp. constitutes a main framework builder together with a complex microbial consortium. This oldest occurrence of Amsassia as a reef builder represents a new record of a skeletal organism in the gap of metazoan reef constructors after the demise of archaeocyaths in the late early Cambrian.
\end{abstract}

\section{Introduction}

The earliest putative corals occur in the early Cambrian. Although many of these generally coralline forms (e.g., the Coralomorpha of Jell, 1984) are of uncertain affinities, among them are undoubted corals (Scrutton, 1997, 1999). The oldest definite tabulate coral, Lichenaria Winchell and Schuchert, 1895, occurs in the Early Ordovician (Scrutton 1979, 1999; Webby et al., 2004). The scarcity of coralomorphs reported from the Cambrian and Early Ordovician contrasts with the diversity of undoubted coral genera recorded after the Middle Ordovician. In this context any finding of coral-like forms from this critical interval significantly contributes to the global diversity, biogeography, and early evolutionary knowledge of corals and coral-like organisms.

Previous works on Paleozoic corals in the Argentine Precordillera (Rodriguez et al., 2002; Fernandez-Martinez et al., 2004; Carrera et al., 2013, and references therein) show records of paleofavositids and sarcinulids from the Middle-Upper Ordovician units, and favositids, pleurodictyids, and rugosans from Silurian and Lower Devonian rocks. The aim of this contribution is to report and describe a tabulate-like coralomorph forming part of boundstones developed within the uppermost Cambrian-lowermost Ordovician that were found in the lower section of the La Silla Formation, Precordillera, western Argentina. This finding represents the oldest record of the genus Amsassia Sokolov and Mironova, 1959. Its association with boundstones and reef-mounds represents the earliest occurrence of this reef-related metazoan found in the gap of reef metazoan constructors after the demise of archaeocyaths in the late early Cambrian. The paleobiogeographic distribution and significance of this new record are discussed.

\section{Geological setting}

The new tabulate-like coralomorph is included within shallowwater subtidal limestones of the La Silla Formation in the Argentine Precordillera (Fig. 1). The La Silla Formation (Keller et al., 1994) is considered to be an ancient tropical Bahamian-type platform (Cañas, 1999; Keller, 1999; Pratt et al., 2012) that accumulated on a uniformly subsiding passive margin within the exotic Precordillera terrane (Astini et al., 1995; Gomez and Astini, 2015). Paleogeographically, by this time, the Precordillera terrane was drifting within the southern Iapetus Ocean (Astini et al., 1995; Benedetto, 2004; Keller, 2012). From a stratigraphic viewpoint, it represents the transition from the late Cambrian largely fossil-barren cyclic peritidal dolomites (Zonda and La Flecha formations) into fossiliferous open-shelf pure limestones of the Ordovician San Juan Formation (Fig. 1.2). However, the highfrequency stacking pattern in the La Silla Formation is more similar to the underlying peritidal La Flecha Formation than to the overlying dominantly subtidal San Juan Formation.

Although there is a clear faunal turnover starting from the La Silla Formation onwards (Cañas and Carrera, 2003), the major change to truly open-marine settings seems to occur at the boundary between the La Silla and San Juan formations (Cañas, 1999; Buggisch et al., 2003; Thompson et al., 2012). Major type 1 sequence boundaries separate the La Silla Formation from the under- and overlying units (Cañas, 1999; Keller, 1999). Accommodation within this largely detached passive-margin setting is interpreted to relate to global sea-level fluctuations rather than with local subsidence (see Astini and Thomas, 1999; Thomas and Astini, 1999).

The La Silla Formation is exposed in several thrust sheets over a distance of more than $350 \mathrm{~km}$ along the Precordillera fold 


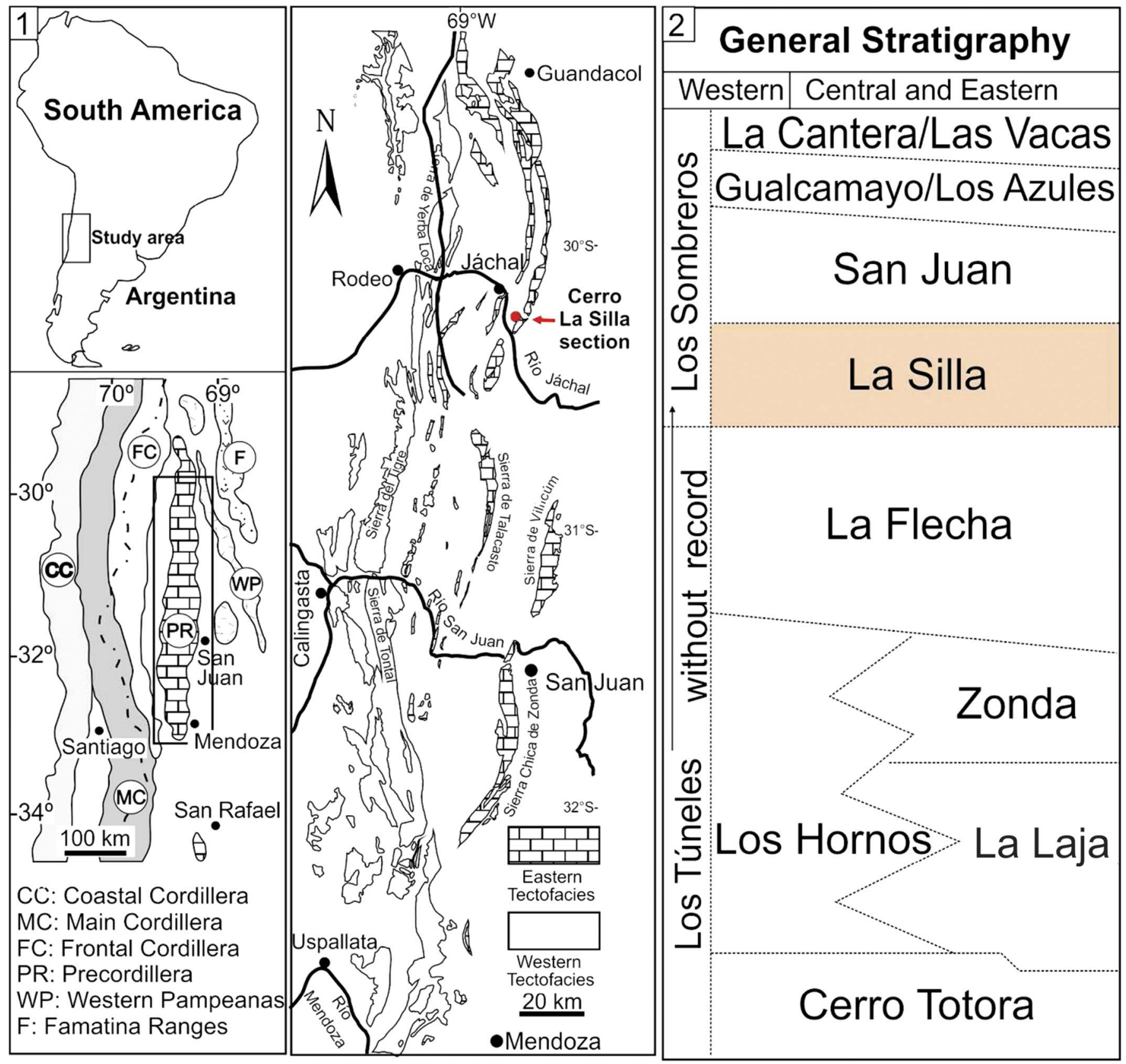

Figure 1. (1) Location map of the Precordillera, showing the major two-fold division in eastern and western tectofacies (Astini, 1992) and the location of the section under study in the Cerro La Silla, type area for the La Silla Formation. The eastern tectofacies are represented by the largely continuous Cambrian to Ordovician passivemargin carbonate platform and overlying black shales and clastic facies that crop out in the central and eastern Precordillera. The western tectofacies is a thick clastic wedge and related mafic volcanic rocks of Middle and Late Ordovician age and mostly represented in the western Precordillera region. (2) Chart of the general stratigraphy of the Precordillera carbonate platform and the evolutive stages for the Cambrian-Ordovician interval. Colored area highlights the unit considered in this study.

and thrust belt in the San Juan Province of western Argentina (Fig. 1). Its massive appearance is in part due to pervasive recrystallization that affects the entire unit. It is chiefly composed of medium- to thick-bedded peloidal-intraclastic-ooidal limestones and thrombolitic biostromes (Cañas and Carrera, 2003), with subordinate amounts of lime mudstones, laminated stromatolitic dolostones, and rare chert. Within its $325 \mathrm{~m}$ of thickness (Fig. 2), three major lower-rank cycles have been recognized (Keller, 1999, 2012; Raviolo et al., 2007), each containing higher-frequency meter-scale cycles that record upward-shallowing trends.
The dominant lithologies in the La Silla Formation (Fig. 3) are peloidal and intraclastic grainstones and packstones, and fewer peloidal wackestones, all of which have been pervasively recrystallized and affected by neomorphism. Pressure-solution seams and stylolites commonly enhance primary facies contacts and bedding pattern. Silicified Thalassinoides paradoxicus (Woodward, 1830) are exceptionally preserved in some beds (Mángano and Buatois, 2003), mostly within the middle and upper section. Facies associations in the La Silla Formation represent persistently highenergy shallow subtidal marine conditions. However, different platform-interior and shelf-lagoonal to tidal-flat subenvironments 


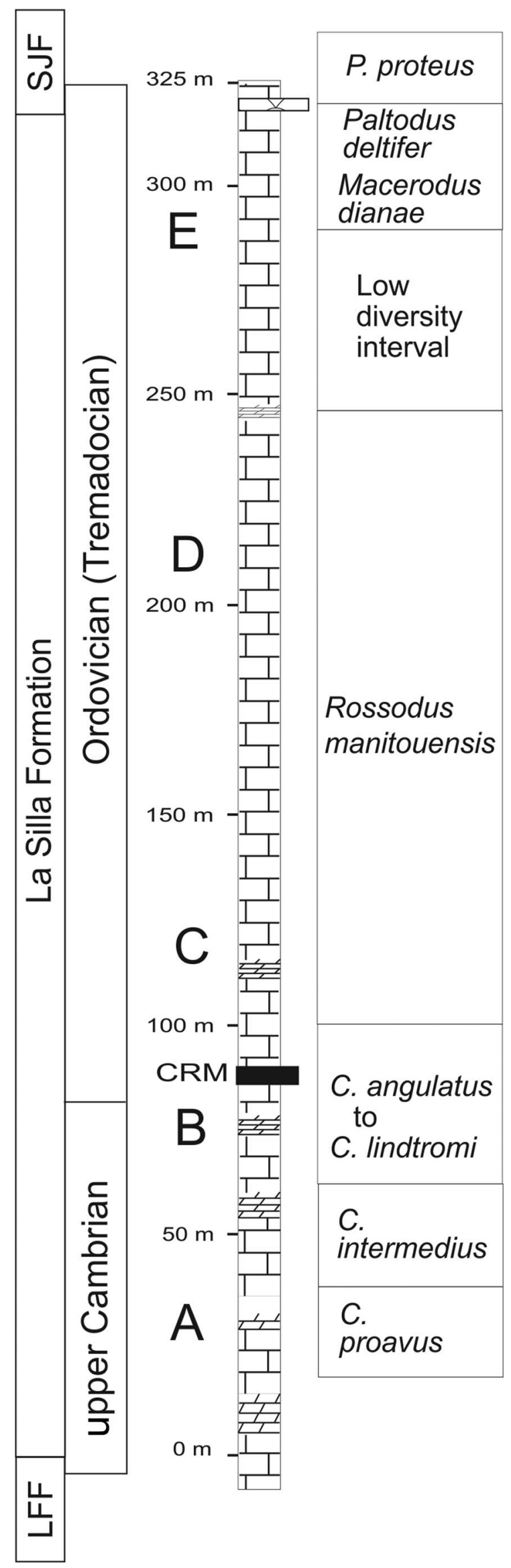

have been recognized (Cañas, 1999; Keller, 1999; Pratt et al., 2012) within the three major subdivisions.

Stromatolites, and particularly thrombolites, are ubiquitous and very common components of the higher-frequency cycles (Armella, 1994; Cañas and Carrera, 2003). Thrombolites vary in diameter from meter scale to several meters, and can be isolated, coalescent, distributed in clusters or patches, and forming laterally persistent biostromes remarkably linked to shallow subtidal high-energy grainy facies (intraclastic to peloidal grainstones). Calcarenites are mainly composed of peloids, well-rounded intraclasts, aggregate lime grains, micritized ooids, and a few bioclasts. Bioclasts are very scarce and include rare calcareous algae such as Nuia sp. and scattered fragments of gastropods, trilobites, and nautiloids within the cross-bedded subtidal grainstone-packstone intervals. Abundant in situ gastropods seem intimately related with domical thrombolites also are common components in associated storm layers and within intercolumnar spaces between domical thrombolites.

Stratigraphic position and age.-The tabulate-like form is included in patchy, mud-rich microbial mounds that grew immediately above the major flooding surface that initiated the second accommodation-related shallowing-upward cycle, $\sim 95 \mathrm{~m}$ above the base of the La Silla Formation (Fig. 2). The fossiliferous level is within the Cordylodus angulatus Conodont Zone (lower Tremadocian), slightly above the CambrianOrdovician boundary, indicated by the presence of the Clavohamulus hintzei and Cordylodus lindstromi zones (Buggisch et al., 2003).

The age of the La Silla Formation has been established by combining information from conodonts and sparse trilobites (Lehnert and Keller, 1993; Keller et al., 1994; Lehnert, 1995; Lehnert et al., 1997; Albanesi and Ortega, 2002). The trilobite Plethopeltis obtusus (Rasetti, 1945), which in North America ranges from the Saukia to the Missisquoia trilobite zones, has been found near the base of the unit (Vaccari, 1994), indicating a late Sunwaptan (late Furongian) age for this part of the section. Four conodont associations were described from intervals B through E within the La Silla Formation (Lehnert, 1995; Buggish et al., 2003).

The oldest recorded conodont fauna of the unit occurs $\sim 55 \mathrm{~m}$ from its base (point B in the section, Fig. 2), containing the species Clavohamulus hintzei Miller, 1969, which is diagnostic of the Clavohamulus hintzei Conodont Subzone of the Cordylodus intermedius Zone. The next conodont fauna (point $\mathrm{C}$ in the section, Fig. 2) was correlated with the Rossodus manitouensis Conodont Zone of the Skullrockian Stage (early Tremadocian) (Ibexian Series) of North America. Point D conodonts were correlated with the 'Low Diversity Interval' and with the lower Macerodus dianae Conodont Zone in North America, whereas point E near the top of the section is correlated with the Paltodus deltifer Conodont Zone, indicating a late Tremadocian age for the top of the La Silla Formation. According to this scheme, the base of the Tremadocian Stage

Figure 2. General stratigraphy and conodont biostratigraphy (from Buggish et al., 2003) of the La Silla Formation. CRM: stratigraphic position of the coralomorph reef-mounds; SJF: San Juan Formation; LFF: La Flecha Formation; A-E: main section points for conodont biozones. 


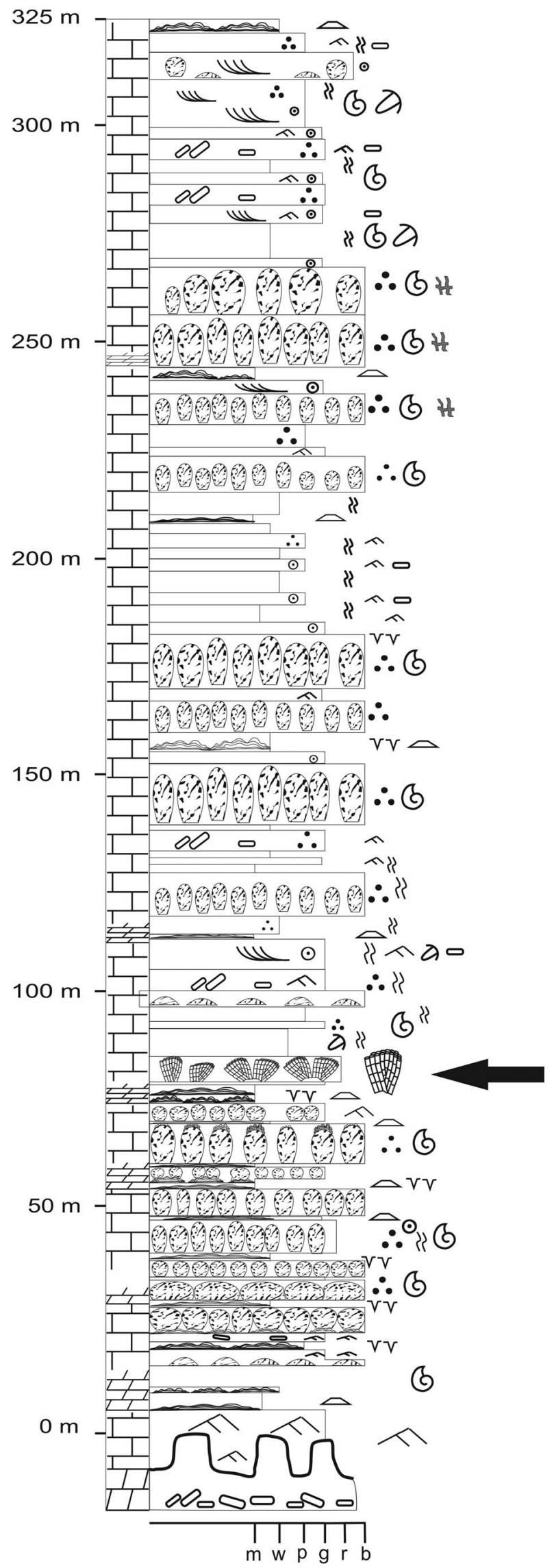

\section{Legend}

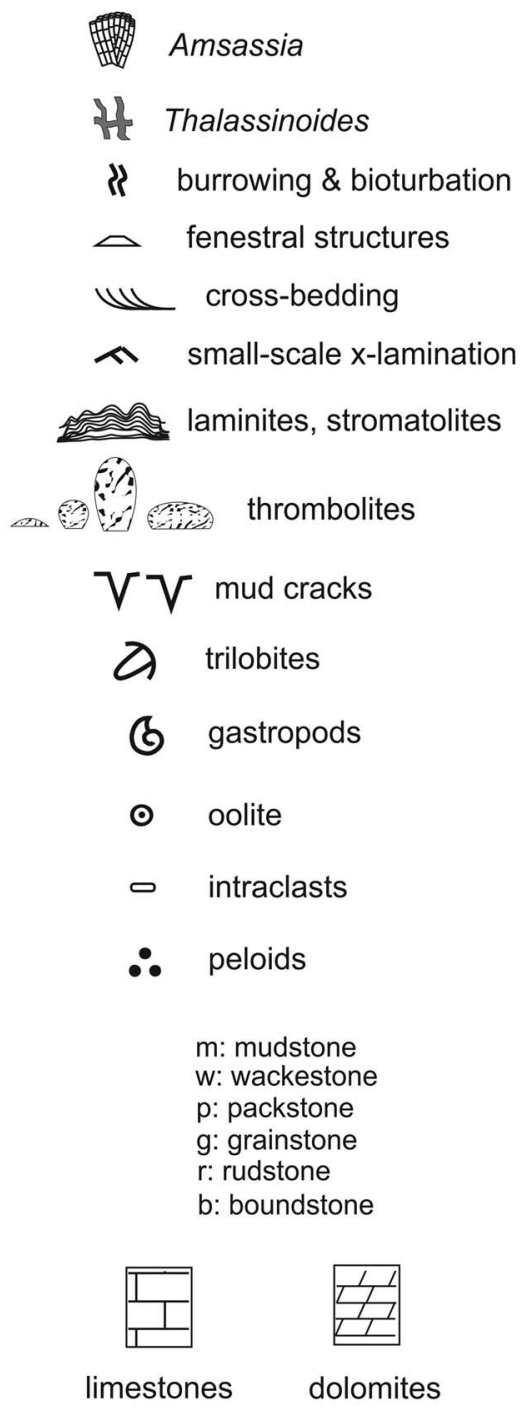

Figure 3. Stratigraphy and facies of the Early Ordovician La Silla Formation, Argentine Precordillera, including location of the coralomorph reef-mound interval (arrow). 


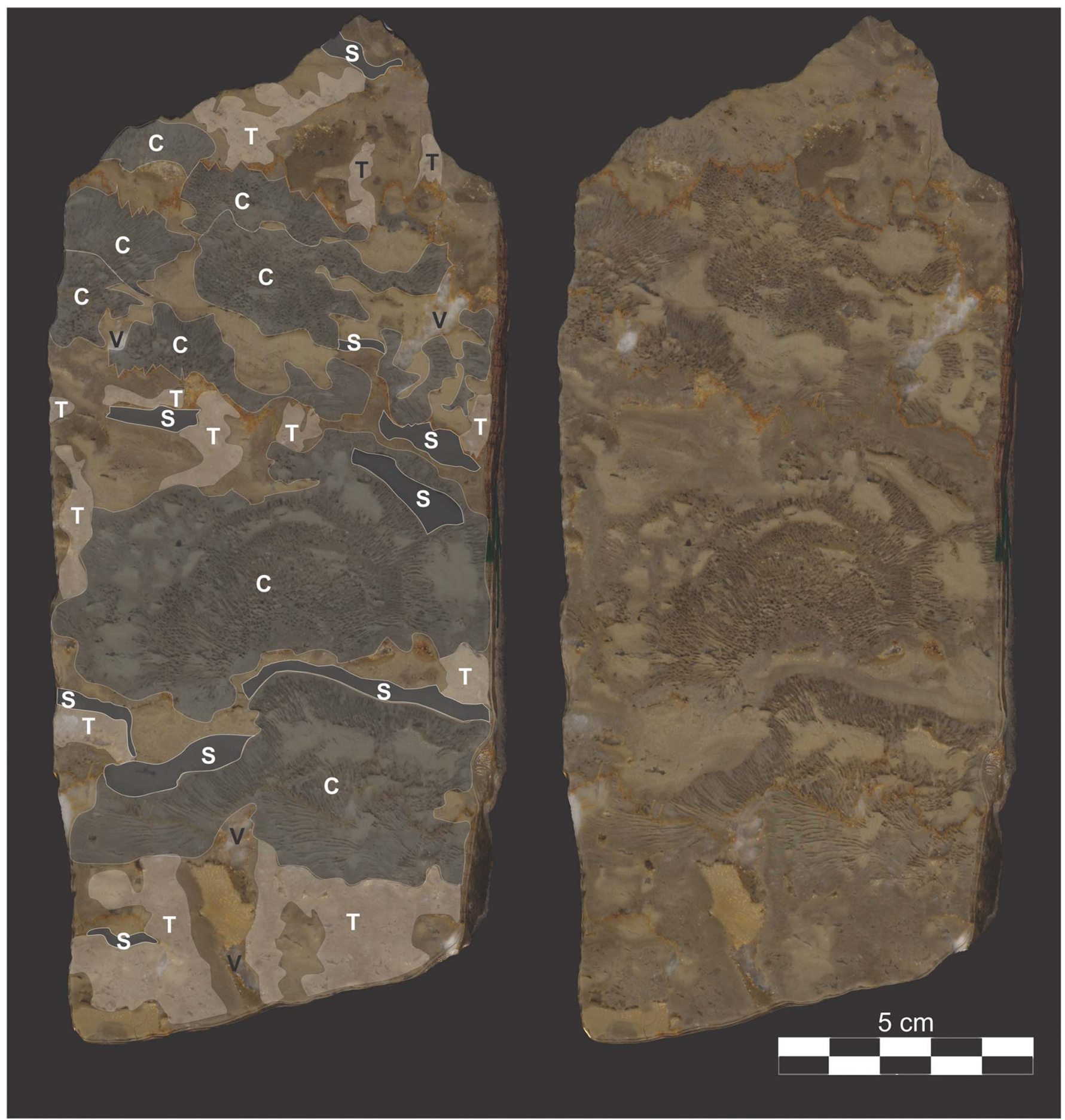

Figure 4. Vertically oriented polished rock slab (CEGH-UNC 26127) from the studied carbonate reef-mounds in La Silla Formation (Lower Ordovician) showing details of main components and their distribution. C: coralomorph (Amsassia colonies, see Fig. 6); S: stromatolite crusts (see Fig. 5.6); T: thrombolite microbialites (see Fig. 5.1, 5.5). Note intimate scaffold development and voids (V) preserved within framework. Also note stylolite development throughout the sample.

(and the Cambrian-Ordovician boundary) lies in the section between points $\mathrm{B}$ and $\mathrm{C}$ at the Cerro La Silla type section, where our fauna was collected (Fig. 2). A detailed carbon isotope record (controlled by conodont assemblages) of the La Silla and San Juan formations was published by Buggisch et al. (2003), presenting an intercontinental correlation of the $\delta^{13} \mathrm{C}_{\text {carb }}$ curve with biostratigraphically well-constrained records of the U.S.A. and Australia. The close match of the curves enabled the authors to place the Cambrian-Ordovician boundary between points B and $\mathrm{C}, \sim 80-90 \mathrm{~m}$ above the base of the La Silla Formation and immediately below our faunas.

Hence, the material under study may come from the lowermost Ordovician levels of the La Silla Formation, belonging to the Cordylodus angulatus Conodont Zone (lower 
Tremadocian), $\sim 20 \mathrm{~m}$ above the Cambrian-Ordovician boundary. These levels probably correlate in time with those of the St. George Group in Newfoundland, but could be slightly older than the thrombolites-Lichenaria mud-mounds of Pratt and James (1982).

Reef-mound interval.-Within the La Silla Formation, benthic biota seems both sparse and low diversity in composition, especially in lacking pelmatozoan ossicles, as Pratt et al. (2012) have pointed out. However, complex microbial consortiums forming thrombolites, the new coralomorph described herein, and calcareous algae such as Nuia sp. begin to occur in these limestones at the lower interval of the unit (uppermost Cambrian-lowermost Ordovician).

The coralomorphs are restricted to a $2 \mathrm{~m}$ thick massive, matrix-rich interval (Fig. 3), where they seem to be in life position. The outcrop is partially covered by debris and vegetation, making it difficult to precisely track the coralomorph-bearing boundstone interval laterally. However, this interval completely disappears laterally at a scale of tens of meters, suggesting low-relief mound geometry.

The individual coralomorphs may be grouped in low-relief (up to $10 \mathrm{~cm}$ ) radial clusters or alternatively may be isolated crusts and slightly broken fragments embedded in peloidal micrograinstones that are intimately associated with various microbial communities. In polished slabs (Fig. 4), radial clusters seem to be passively covered by laminated peloidal muds or abruptly truncated by rugged surfaces capped by peloidal grainstones (Fig. 5). Within the grainstones, the calcareous alga Nuia sp. is present (Fig. 5.3). Radial clusters seem to be nucleated on the peloidal intraclastic grainstones (hardgrounds) or directly stacked on small-diameter domical microbial heads. Intercolumnar spaces between coral clusters are alternatively filled by peloidal muds, peloidal grainstones, or complex calcified microbial consortiums (Fig. 5). This allows for the interpretation that colonial growth occurred synchronous with energy fluctuations and somehow colonies were interacting with microbial communities and periodically interrupted by higherenergy events, developing erosion surfaces, and grainy facies. Microscopic observations in thin sections seldom show terminal module walls protruding out of these irregular surfaces, indicating that not all of these surfaces are strictly erosive, but depositional. Irregular micritic to micropeloidal laminae, occasionally with filamentous textures, point to a stromatolitelike habit and trapping and binding processes. Microscopically clotted-peloidal dense micrite with diverse shapes and growth patterns suggest pervasive bacterially induced precipitation within microbial biofilms, as well as cryptic microbialites
(Chafetz, 1986; Reitner, 1993; Riding, 2002; Adachi et al., 2004; Flügel, 2004; Chen and Lee, 2014). As pointed out in other examples (e.g., Sun and Wright, 1989; Riding and Tomas, 2006), microbial textures occur both as irregularly laminated crusts on framework elements, as complex open-cavity fills within the boundstone framework, and as internal fills in cavities (intraskeletal and boring). Among distinct cavity-filling microbial consortiums, we recognized Renalcis-like chamber arrays (Fig. 5.1) (e.g., Riding, 1991; Chafetz and Guidry, 1999; Riding and Fan, 2001; Stephens and Sumner, 2002), as well as dendritic forms (Fig. 5.5) (e.g., Pratt and James, 1982; Pratt, 1984; Riding, 1991; Shen et al., 1997) and clustered globous forms (Fig. 5.4). Internal fills have a patchy intraskeletal clotted homogeneous pattern (Figs. 5, 6) and may correspond to later eodiagenetic non-photosynthetic cryptic bacteria that grew within available pore spaces, largely represented by decaying of coralomorph colonies.

Most of the microfacies, including the microbial peloidalclotted matrix, the grainstones, and the coralomorph clusters themselves, are sparsely bioturbated. Field, slab-, and thinsection analysis is consistent with a combination of processes typical of microbial boundstones and microbial-coralomorph boundstones. Due to their relative abundance, the complex microbial consortium, together with the coralomorphs, seems to represent the major framework builders in our case. During their growth and metabolic activities, microbes and cyanobacteria may have induced calcite precipitation in cyanobacterial filaments, algal sheaths, and extra-polymeric substances (EPS) within the boundstone and/or periodically helped trap and bind lime peloidal muds that in some cases seem to drape coralomorph colonies (Fig. 4). Together with early cementation, microbial activity may have contributed to substrate stabilization, encrustation, and development of the metazoan (coralomorph) skeletal frameworks. It is therefore evident that microbes may have played roles as binders and substrate stabilizers, further allowing encrustation by coralomorphs. It is also clear that erosion and fragmentation periodically affected these low-relief reef-mounds, as suggested by the presence of irregular erosive surfaces (Fig. 5.3) and interbedded peloidal intraclastic grainstones with fragmented and disrupted colonies.

Repository and institutional abbreviation.-The specimens are housed under the prefix CEGH-UNC in the paleontological collection of Centro de Investigaciones Paleobiológicas (CIPAL), at the building of Centro de Investigaciones en Ciencias de la Tierra (CICTERRA), Universidad Nacional de Córdoba, Argentina.

\footnotetext{
Figure 5. Thin section photomicrographs and boundstone petrography showing textures and distinct microbial components, including Amsassia argentina $\mathrm{n}$. sp. colonies; scale bars $=1 \mathrm{~mm}$, except in Fig. 5.3: (1) Renalcis-like chambers (white arrows) isolated and forming arrays within the microbial consortium growing towards center of cavity (filled with sparite); (2) view of the colony in sharp contact with a peloidal grainstone through a stylolite (white arrow); (3) peloidal grainstone overlying a cemented erosive surface (hardground). Note oblique section of Nuia sp. (black arrow) within grainstone, scale bar $=0.5$ mm; $(4)$ detail of termination of a colony showing a complex microbial consortium with chambered, dentritic, filamentous, and globous forms growing toward a framework reef cavity; (5) similar to 4 . Note the contrast between cryptic microbial communities (represented by homogeneous clotted peloidal automicrite) growing within modules (black arrow) and those more oriented forms colonizing the surface (white arrow); (6) finely laminated peloidal micrograinstone (stromatolite crust, black arrow) draping the termination of a colony. Note trilobite section (white arrow) and other bioclasts within upper part of photograph and some infiltration within the upper modules of the underlying colony. 1, 2, $\mathbf{4}, \mathbf{5}$ and $\mathbf{6}$ show partial views of longitudinal to transverse sections of Amsassia colonies. Note that in most cases, individual modules are partly occluded by homogeneous clotted automicrite of bacterial origin.
} 


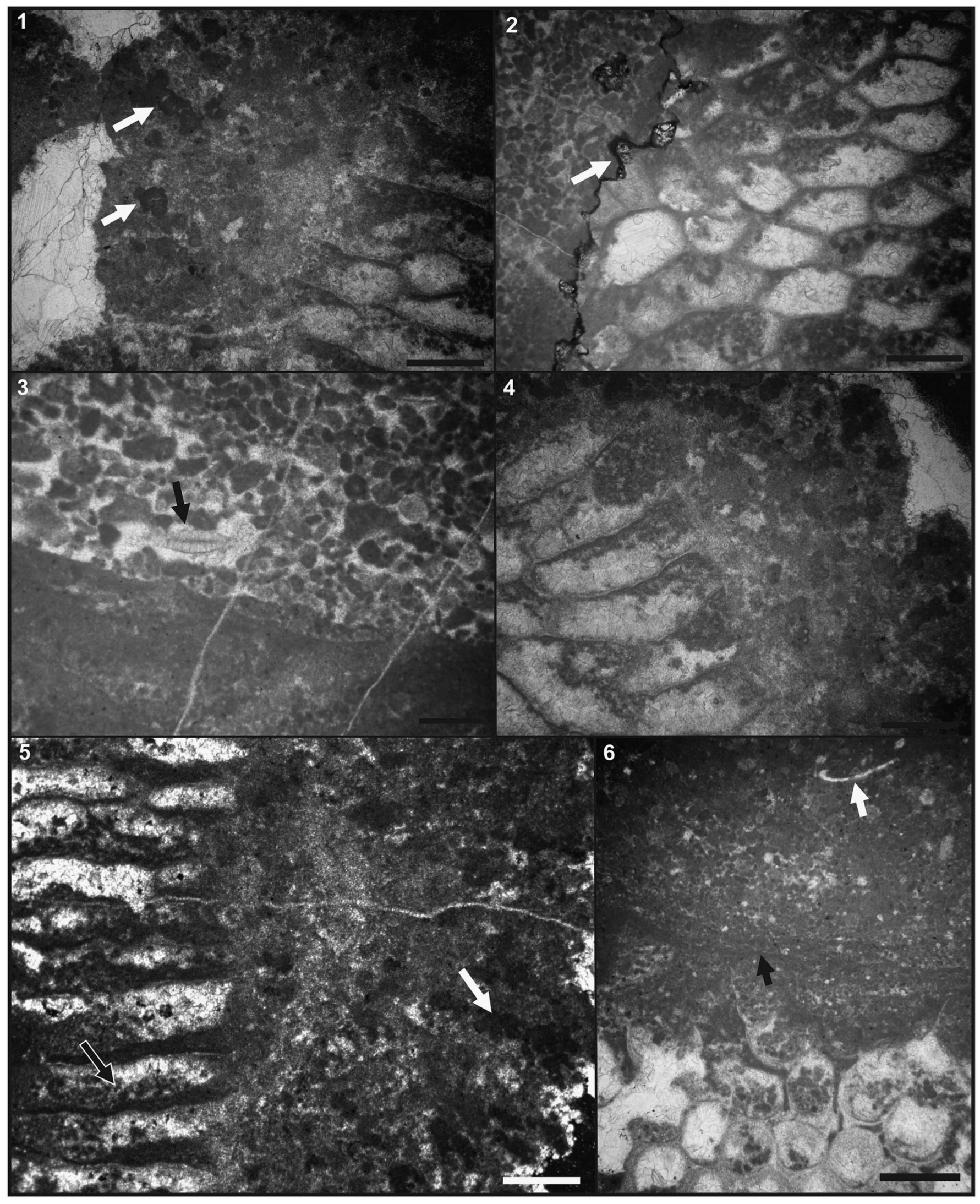




\section{Systematic paleontology}

“Coralomorpha" (Jell, 1984; Scrutton, 1997)

Remarks.-The calcified modular skeletons of several organisms have similarities with coralline organization. Most of these forms were recorded in the Cambrian (e.g., Rosellatana Kobluk, 1984; Flindersipora Lafuste et al., 1991; Moorowipora Fuller and Jenkins, 1994; Tabulaconus Handfield, 1969; Harklessia Hicks, 2006). All these coral-like forms were grouped under the informal name Coralomorpha, or the more formal Tabulaconida Scrutton, 1997 for tabulate-like forms (Jell, 1984; Debrenne et al., 1987; Zhuravlev et al., 1993; Scrutton, 1997). Tabulata Milne-Edwards and Haime, 1850 is now regarded as a cohesive group (Scrutton, 1979, 1984; Hill, 1981; Pandolfi, 1989), with Lichenaria as the oldest ancestral genus. However, some uncertainties as to the taxonomic position still exist among the stock of early basal coralomorphs and tabulate-like forms recorded from the lower Cambrian to the Lower Ordovician.

We use the term Coralomorpha as an informal name with no phylogenetic implications. The genus Amsassia is provisionally included in this morphologic group after the comprehensive reevaluation performed by Sun et al. (2014) of this problematic organism with uncertain affinities.

Genus Amsassia Sokolov and Mironova, 1959

Type species.-Amsassia raduguini Mironova in Sokolov and Mironova, 1959 from the Amsass Suite, Upper Ordovician of Shoria Mountains, western Siberia.

\section{Amsassia argentina new species}

Figures 5, 6

Holotype and other material.-Holotype CEGH-UNC 26119. Other material: CEGH-UNC 26120-26127 (8 complete and fragmentary colonies in thin sections and polished slabs). All specimens are from the base of the La Silla Formation, Lower Ordovician, Cordylodus angulatus Conodont Zone (lower Tremadocian), San Juan Province, western Argentina.

Diagnosis.-Growth form massive, tabular, domical to foliaceous or irregular. Structure mainly cerioid to phacelocerioid in some areas. Transverse shape of modules rounded to subpolygonal in loosely packed areas (module diameter 0.4$0.8 \mathrm{~mm}$ ) to polygonal in densely packed areas (module diameter $0.5-1.1 \mathrm{~mm}$ ). Module wall fibrous, with median line between adjoining modules. Module increase by longitudinal fission. Tabulae rare, irregularly spaced, bowed downward.
Description.-Growth form massive, tabular, domical to foliaceous or irregular. Structure mainly cerioid to phacelocerioid; size up to $170 \mathrm{~mm}$ across, $70 \mathrm{~mm}$ high. In transverse section, modules generally polygonal to subpolygonal and closely packed, ranging from quadrate through circular to irregular in loosely packed areas. Maximum diameter $0.5-1.1 \mathrm{~mm}$ in areas of polygonal modules, $0.4-0.8 \mathrm{~mm}$ in areas of subpolygonal to rounded modules (Table 1). In longitudinal section, module walls relatively straight to gently undulate. Tabulae rare, very thin, complete or partially aborted, usually concave. Incomplete tabulae short and thick, or long with sharp tips pointed downwards (Fig. 6.8). When tabulae present, commonly bowed (downward), most of them complete, $<0.01 \mathrm{~mm}$ thick and irregularly spaced, $\sim 0.8-2 \mathrm{~mm}$ apart.

Pores or wall discontinuities related with dissolution or with different types of longitudinal fission. Module increase by longitudinal fission, in most cases bipartite, but tripartite observed in some sections.

Module wall thickness fairly uniform, $\sim 0.09-0.1 \mathrm{~mm}$, walls generally fibrous or have microgranular areas. Microstructure variously preserved; observed clearly where module wall is well preserved. Dark median line visible where adjoining modules are in contact, with a thick fibrous outer wall on both sides, perpendicular to median line (fibro-normal coating) (Fig. 6.5).

Etymology. - The new species is named for Argentina.

Remarks.-Amsassia argentina $\mathrm{n}$. sp. shows cerioid to phacelocerioid massive colonies, polygonal, subpolygonal, to rounded modules, scarce tabulae when present, and axial increase by longitudinal fission. All these characteristics are found in the coralomorph Amsassia, (Hill, 1981; revised in Sun et al., 2014; M. Lee et al., 2016), which is diagnosed by the co-occurrence of cerioid and phaceloid growth forms, with the transverse shape of modules rounded in loosely packed areas to polygonal in densely packed areas. The diameter of modules in the genus ranges from 0.06 to $1.7 \mathrm{~mm}$. Module increase by longitudinal fission may be bipartite, tripartite, or quadripartite. Tabulae are rare.

Although size and shape of modules are highly variable in Amsassia, in the Argentinean material the polygonal module diameter in cerioid areas is considerably bigger than the rounded module diameter. This is uncommon in the other species of Amsassia. The size of the modules (between 0.4 and $1.1 \mathrm{~mm}$ ) distinguishes our material from the ranges of size variation recorded in other species of the genus (reviewed in Sun et al.,

\footnotetext{
Figure 6. Thin section photomicrographs of Amsassia argentina $\mathrm{n}$. sp.: (1) a colony in longitudinal section $\mathrm{CEGH}-\mathrm{UNC} 26120$, scale bar $=5 \mathrm{~mm}$; $(\mathbf{2})$ complete view of the transversal section of holotype CEGH-UNC 26119 , scale bar $=5 \mathrm{~mm}$; (3) transversal section of a colony showing the conspicuous infilling of peloidal grains, CEGH-UNC 26121, scale bar = $2 \mathrm{~mm}$; (4) close up of holotype CEGH-UNC 26119 showing arrangements of the polygonal modules and diagenetically dissolved areas, scale bar $=1 \mathrm{~mm}$; $(\mathbf{5})$ close up of Fig. 6.4 showing module wall with a thick outer wall on both sides and fibrous structures perpendicular to the median line, scale bar $=0.5 \mathrm{~mm} ;(\mathbf{6})$ transverse section showing wall discontinuities and the ceroid to phaceloid structure, $\mathrm{CEGH}$-UNC 26122, scale bar = $1 \mathrm{~mm}$; (7) longitudinal section of a colony showing long slender and slightly sinuousmodules, without (or missing) tabulae, with axial longitudinal increase (arrow), CEGH-UNC 26123, scale bar $=2 \mathrm{~mm} ;(\mathbf{8}, \mathbf{9})$ longitudinal views of modules with regularly distributed tabulae, CEGH-UNC 26124 , both scale bars $=1 \mathrm{~mm}$; (10) longitudinal section showing the flexuous development of modules and scarcity of tabulae, CEGH-UNC 26125, scale bar $=5 \mathrm{~mm}$; (11) longitudinal section in holotype CEGH-UNC 26119 showing development of longitudinal increase $($ arrow $)$, scale bar = 2 mm; $(\mathbf{1 2})$ transversal section of holotype CEGH-UNC 26119 showing polygonal modules, scale bar $=1 \mathrm{~mm}$.
} 

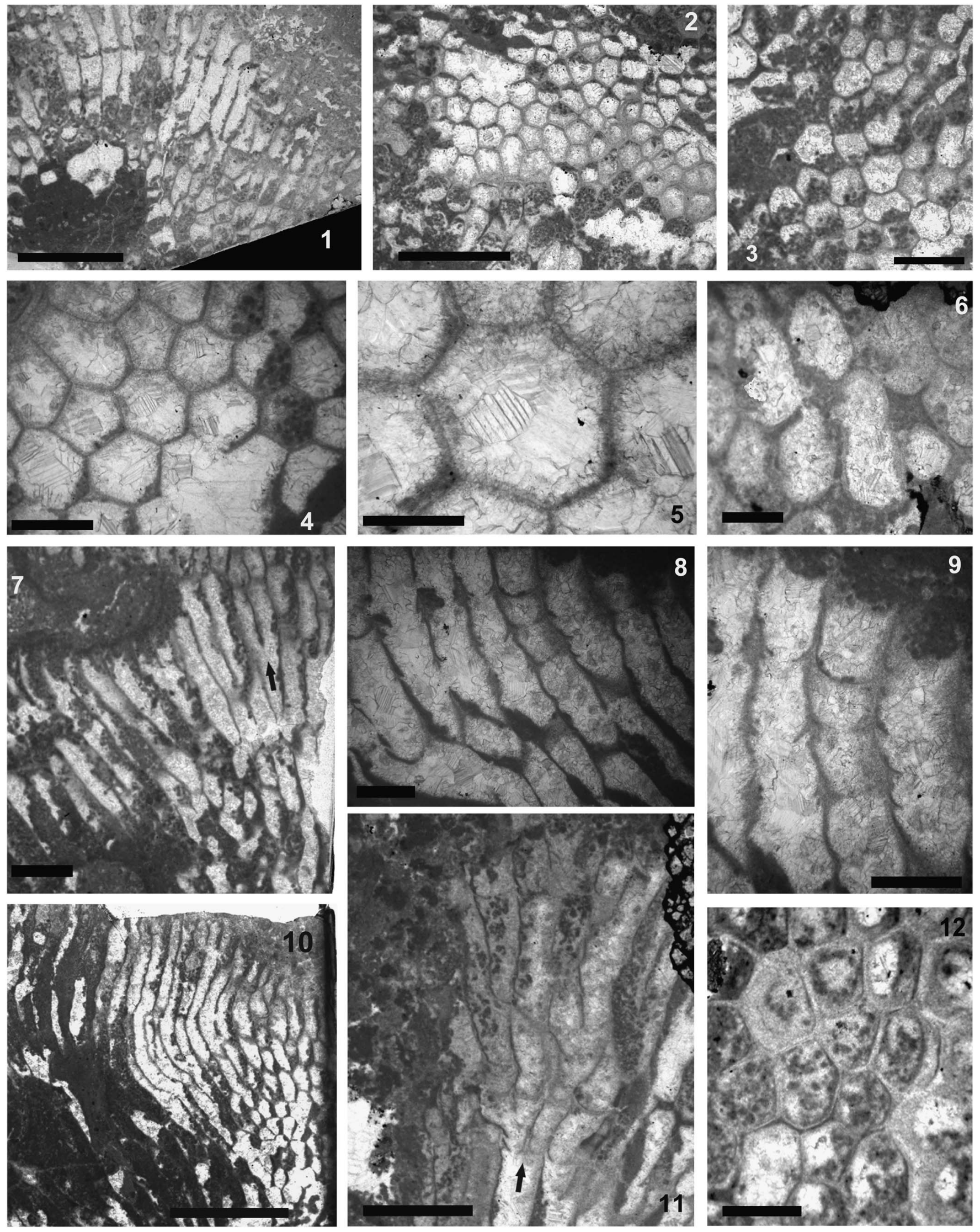
Table 1. Module diameter of Amsassia argentina n. sp. For seven specimens from La Silla Formation, two distinct areas within a transverse thin section were sampled, characterized by polygonal and subpolygonal to rounded modules. Polygonal module diameter $=($ long axis + short axis $) / 2$. Abbreviations: Max., maximum diameter (mm); Min., minimum diameter (mm); Avg., average diameter (mm); SD, standard deviation; n, number of modules.

\begin{tabular}{lccccc}
\hline Module shape & Max. & Min. & Avg. & SD & $\mathrm{n}$ \\
\hline Polygonal & 1.12 & 0.53 & 0.87 & 0.14 & 38 \\
Subpolygonal to rounded & 0.84 & 0.44 & 0.54 & 0.11 & 41 \\
\hline
\end{tabular}

2014; M. Lee et al., 2016). The Argentinean material is assigned to a new species, A. argentina.

Species of Amsassia reported from northern Kazakhstan and western Siberia have module diameters that are less variable in size than A. argentina $\mathrm{n}$. sp.: A. princeps $(0.73-1.0 \mathrm{~mm}$; Sokolov and Mironova, 1959), A. chaetetoides (1.0-1.4 mm; Sokolov and Mironova, 1959), and the type species A. raduguini (1.1-1.4 mm; Sokolov and Mironova, 1959).

Amsassia shaanxiensis from northern China (Sun et al., 2014) has modules generally polygonal to subpolygonal and closely packed, rarely rounded, and partially to entirely separated, with module diameter ranging from 0.46 to $1.66 \mathrm{~mm}$, which is larger than in A. argentina $(0.41-1.11 \mathrm{~mm})$.

Amsassia koreanensis M. Lee et al., 2016 was described from Korea and China. This form has an exceptionally small module diameter $(0.06-0.28 \mathrm{~mm})$, which is different from the size range observed in A. argentina.

Other species reported from China and Mongolia, include A. minima $(0.2-0.4 \mathrm{~mm}$; Yang et al., 1978), A. tudiaoensis (0.3-0.6 mm; Yang et al., 1978), A.(?) minima (0.3-0.5 mm; Lin and Chow, 1980), and A. sheshanensis (Deng, 1984; Ye et al., 1995), all with smaller module diameters and narrower size ranges than A. argentina n. sp. Amsassia soluta and A. abnormis ( $\mathrm{Yu}, 1962)$ have a range of variation (0.5-1.1 mm; M. Lee et al., 2016) that almost overlaps the range observed in A. argentina $\mathrm{n}$. sp. However, module diameters of $0.3-0.4 \mathrm{~mm}$ are found in our material, measured in loosely packed areas.

The dark median line separating adjacent modules, visible in some sections, could be related with early diagenesis, and apparently not related with the presence of a true medial plate or fused epithecae of adjacent modules. Unfortunately, poor preservation prevents a complete analysis of this aspect.

Amsassia is a problematic modular organism with a corallike skeleton that recently was reevaluated by Sun et al. (2014) and M. Lee et al. (2016). After a comprehensive analysis, Amsassia was compared with different types of corals, tetradiids, chaetetid sponges, and algae, those authors suggested that Amsassia may represent an extinct group of calcareous algae.

Lichenaria is a common Lower and Middle Ordovician tabulate, considered the basal genus in the early radiation of tabulates (Scrutton, 1984, 1997; Pandolfi, 1989). In species of Lichenaria, the corallites exclusively show a cerioid structure and are separated by fibrous, continuously fused common walls. The septal structures are absent and it has abundant tabulae (Elias et al., 2008, and references therein). Lichenaria grew exclusively through lateral corallite increase, which is considered to be the key feature for identifying the genus (Elias et al.,
2008). All these characteristics clearly separate our material from the lichenariid stock.

\section{Paleogeographic distribution of Amsassia and its role in the early development of metazoan reefs}

In the last few years, there have been several new contributions on upper Cambrian to Lower Ordovician reefs and reef-related organisms (Adachi et al., 2009, 2012a, b, 2015; Hong et al., 2012, 2015; Wang et al., 2012; Choh et al., 2013; Kruse and Reitner, 2014; Lee et al., 2014, and references therein). Those studies have begun to fill in the well-known gap in metazoan reef records after the demise of archaeocyaths in the late early Cambrian (Pratt et al., 2001; Webby, 2002; Rowland and Shapiro, 2002).

After collapse of the early Cambrian calcimicrobialarchaeocyathan reef consortium, metazoans played little part in reef construction for ca. $30 \mathrm{Myr}$ (Rowland and Shapiro, 2002; Adachi et al., 2015). Many reef-mound findings in the post-extinction interval were completely constituted by microbes (Webby, 2002; Rowland and Shapiro, 2002; Lee et al., 2015).

Nevertheless, exceptional metazoan reefs have been documented from the interval commencing around the beginning of the Furongian Epoch, when spiculate sponges began to actively participate in reef construction. Some of these reefs are mainly microbial, but demosponges helped as secondary reef builders (Cañas and Carrera, 1993; Riding and Zhuravlev, 1995; Shapiro and Rigby, 2004; Kruse and Zhuravlev, 2008; Wang et al., 2012; Choh et al., 2013; Kruse and Reitner, 2014) (mainly summarized in Rowland and Shapiro, 2002; Hong et al., 2012; Adachi et al., 2015).

Orchoclad demosponges diversified in the late Cambrian as the main metazoan constituents of reef settings. Orchoclads, in particular the anthaspidellids, had tough, ladder-like, desmabased skeletal construction that allowed them to occupy highenergy reef environments (Carrera and Botting, 2008).

Other mainly Early Ordovician reef-related metazoans are the receptaculitid calathids, which commonly are associated with the orchoclad demosponges and recognized as accessory reef constructors (Carrera, 1991; Church, 1991; Cañas and Carrera, 1993; Liu et al., 2005; Adachi et al., 2012a; Hong et al., 2012; Wang et al., 2012; Choh et al., 2013; Li et al., 2015). Calathids are not as diverse as the orchocladine demosponges, but show a widespread distribution (Rowland and Shapiro, 2002; Webby, 2002; Wang et al., 2012).

The stromatoporoids or stromatoporoid-like organisms, commonly domical or encrusting forms, became frame builders or accessory frame builders in varying degrees by the early Tremadocian (Toomey and Nitecki, 1979; Keller and Flügel, 1996; Webby, 2002; Cañas and Carrera, 2003; Zhen and Picket, 2008). Pulchrilamina Toomey and Ham, 1967 from the Lower Ordovician of Utah and New Mexico (Toomey and Nitecki, 1979) was one of the oldest recorded forms. New records of Lower Ordovician reef-related stromatoporoids have been reported from China and Korea (J.-H. Lee et al., 2016; Li et al., 2016). Stromatoporoids and stromatoporoid-like organisms were classically recognized as frame builders because of their 
size and dome shaped or encrusting laminar forms. They are widespread, but mainly well developed in North America and China, and less frequent in South America and Australia. Later, they became the main reef constructors in Silurian and Devonian carbonate platforms.

Bryozoans have also been found associated with Ordovician reef mound structures, assuming a constructional role (Adachi et al., 2012b; Cuffey et al., 2013). The main framework of these reef structures was shared with demosponges, calcimicrobes (Girvanella Nicholson and Etheridge, 1878), and the stromatoporoid Pulchrilamina.

Corals were minor components of reefs structures during the Early Ordovician. The Lichenaria specimens, recognized by Pratt and James (1982) in Newfoundland, are included in small thrombolite mounds or small bioherms composed of a microbeLichenaria-Renalcis boundstone (Pratt and James, 1982).

The coralomorph Amsassia was recently reported from north-central China as an important component of Middle Ordovician reef assemblages (Lee et al., 2014). The reef-mound structure is characterized by peloidal masses composed of aggregated peloids, micrites, and bundles of tubular calcimicrobes, with the subordinate Amsassia, the calcimicrobe Ortonella Garwood, 1914, green algae, and tetradiids.

Amsassia argentina $\mathrm{n}$. sp. is abundant, dome shaped, and represents an important proportion, clearly $>50 \%$, of the Lower Ordovician reef framework in western Argentina. These characteristics suggest that this form had a dominant role in the skeletal framework construction. It can be considered a main frame builder associated with a complex microbial-algal consortium composed of renalciforms, Nuia Maslov, 1954, and a variety of thrombolites and small stromatolites. This structure differs slightly in composition and proportions from the younger Amsassia reef framework in north-central China (Lee et al., 2014).

Amsassia was reported from the western margin of Gondwana around the Sino-Korean and Tarim blocks from the middle part of the Middle Ordovician (M. Lee et al., 2014, 2016, and references therein), and wider occurrences have been reported from the early Late Ordovician of Kazakhstan (e.g., Popov et al., 2002), Siberia (Bondarenko and Ulitina, 2009), and a single report from the Late Ordovician of Laurentia (Bolton, 2000).

Discovery of Amsassia in the lowermost Ordovician modifies the paleogeographic scenario envisaged by M. Lee et al. $(2014,2016)$. These authors suggested that Amsassia emerged in western Gondwana (Sino-Korean and Tarim blocks), where the genus appears to have originated in the Middle Ordovician, and might subsequently have spread into Kazakhstan and Siberia prior to the early Late Ordovician.

With this new discovery in the Lower Ordovician of Argentina, the spatio-temporal distribution of Amsassia is substantially modified: its origination and migration pathway is significantly changed. This new record shows that Amsassia emerged from the eastern margin of Laurentia, since the Argentine Precordillera rifted from this continent by the late Cambrian (Astini et al., 1995; Benedetto, 2004). Subsequent records occur in the Middle Ordovician of the Sino-Korean and Tarim block (Lee et al., 2014), and later the expansion continued in Siberia and Kazakhstan. The record in Canada (Bolton, 2000) by the early Late Ordovician can be explained by its proximity with the Siberian block. The presence of Amsassia in the "Laurentian stage" of the Argentine Precordillera suggests that we should expect Lower or Middle Ordovician Laurentian records between the Lower Ordovician occurrence of Amsassia in the Argentine Precordillera and their subsequent presence in the Late Ordovician of Canada. This probably reflects a gap in the sampling record more than a true dispersion pattern. However, as Sun et al. (2014) pointed out, there is a critical need to re-examine the species previously referred to Lichenaria or Amsassia, which have been commonly misidentified.

By the late Cambrian and Early Ordovician, a variety of metazoan forms occupied the niches left by archaeocyaths with varying degrees of success. All these metazoan forms were aided in reef or biostrome construction by microbes. Large-sized organisms (orchoclad demosponges, calathids, stromatoporoids) could easily form the scaffold structure of the framework, and usually required a smaller proportion of microbes or other secondary constructors. In our example, it is clear that the high proportion of Amsassia colonies represented in the boundstone, the coalescent arrangements, and the stacking patterns they acquired, enabled them to be the primary scaffolding organism of the reef framestone. The new paleogeographic scenario shows that Amsassia acquired a worldwide distribution with a significant participation in reef construction and represents a successful attempt of skeletal organisms to construct reefs during the Early to Middle Ordovician interval.

\section{Acknowledgments}

The authors acknowledge support from the National Research Council of Argentina. MGC acknowledges support from CONICET (Grant PIP 2009- 00861). RAA acknowledges support from SECYT-UNC 213/14. Appreciation is extended to the reviewers, G.A. Young and D.-J. Lee, for their helpful comments and suggestions that significantly improved the final version of the manuscript. We would also like to thank the editorial staff of the Journal for their assistance. This is a contribution to the IGCP 653 project, "The onset of the Great Ordovician Biodiversity Event".

\section{References}

Adachi, N., Ezaki, Y., and Liu, J., 2004, The fabrics and origins of peloids immediately after the end-Permian extinction, Guizhou Province, South China: Sedimentary Geology, v. 164, p. 161-178.

Adachi, N., Ezaki, Y., Liu, J., and Cao, J., 2009, Early Ordovician reef construction in Anhui Province, South China: a geobiological transition from microbial- to metazoan-dominant reefs: Sedimentary Geology, v. 220, p. $1-11$.

Adachi, N., Liu, J., and Ezaki, Y., 2012a, Early Ordovician reefs in South China (Chenjiahe section, Hubei Province): deciphering the early evolution of skeletal-dominated reefs: Facies, v. 59, p. 451-466.

Adachi, N., Ezaki, Y., and Liu, J., 2012b, The oldest bryozoan reefs: a unique Early Ordovician skeletal framework construction: Lethaia, v. 45, p. 14-23.

Adachi, N., Kotani, A., Ezaki, Y., and Liu, J., 2015, Cambrian Series 3 lithistid sponge-microbial reefs in Shandong Province, North China: reef development after the disappearance of archaeocyaths: Lethaia, v. 48, p. 405-416.

Albanesi, G.L., and Ortega, G., 2002, Advances on conodont-graptolite biostratigraphy of the Ordovician System of Argentina, in Aceñolaza, F.G., ed., Aspects on the Ordovician System in Argentina: INSUGEO, Serie Correlación Geológica, v. 16, p. 143-165.

Armella, C., 1994, Thrombolitic-stromatolitic cycles of the Cambro-Ordovician boundary sequence, Precordillera Oriental basin, western Argentina, in Bertrand-Sarfati J., and Monty, C., eds., Phanerozoic Stromatolites II: Dordrecht, Kluwer Academic, p. 421-441. 
Astini, R.A., 1992, Tectofacies ordovícicas y evolución de la cuenca eopaleozoica de la Precordillera Argentina: Estudios Geológicos, v. 48, p. 315-327.

Astini, R.A., and Thomas, W.A., 1999, Origin and evolution of the Precordillera terrane of western Argentina. A drifted Laurentian orphan, in Ramos, V.A., and Keppie, D., eds., Laurentia-Gondwana Connections Before Pangea: Geological Society of America Special Paper, v. 336, p. 1-20.

Astini, R.A., Benedetto, J.L., and Vaccari, N.E., 1995, The Early Paleozoic evolution of the Argentine Precordillera as a Laurentian rifted, drifted and collided terrane: a geodynamic model: Geological Society of America Bulletin, v. 107, p. 253-273.

Benedetto, J.L., 2004, The allochthony of the Precordillera ten years later (19932003): a new paleobiogeographic test of the microcontinental model: Gondwana Research, v. 7, p. 1027-1039.

Bolton, T.E., 2000, Ordovician megafauna, southern Baffin Island, Nunavut: Geological Survey of Canada, Bulletin, v. 557, p. 39-158.

Bondarenko, O.B., and Ulitina, L.M., 2009, Ordovician corals of the Siberian and Mongolian basins: taxonomic diversity, morphogenesis, and occurrence: Paleontological Journal, v. 43, p. 1439-1457.

Buggisch, W., Keller, M., and Lenhert, O., 2003, Carbon isotope record of the Late Cambrian to Early Ordovician carbonates of the Argentina Precordillera: Palaeogeography, Palaeoclimatology, Palaeoecology, v. 195, p. 357-373.

Cañas, F.L., 1999, Facies and sequences of the Late Cambrian-Early Ordovician carbonates of the Argentine Precordillera: a stratigraphic comparison with Laurentian platforms, in Ramos, V.A., and Keppie, J.D., eds., LaurentiaGondwana Connections Before Pangea: Geological Society of America Special Paper, v. 336, p. 43-62.

Cañas, F., and Carrera, M., 1993, Early Ordovician microbial-sponge receptaculitid bioherms of the Precordillera, western Argentina: Facies, v. 29, p. $169-178$

Cañas, F.L., and Carrera, M.G., 2003, Precordilleran reefs, in Benedetto, J.L., ed., Ordovician Fossils of Argentina: Córdoba, Secretaría de Ciencia y Tecnología, Universidad Nacional de Córdoba, p. 131-153.

Carrera, M.G., 1991, Los géneros Selenoides Owen y Calathium Billings (Receptaculitaceae) en el Ordovícico de la Precordillera de San Juan, Argentina: Ameghiniana, v. 28, p. 375-380.

Carrera, M.G., and Botting, J., 2008, Evolutionary history of Cambrian spiculate sponges: implication for the Cambrian evolutionary fauna: Palaios, v. 23, p. $124-138$.

Carrera, M.G, Montoya, E., Rustan, J., and Halpern, K., 2013, SilurianDevonian coral associations across a sequence stratigraphic boundary in the Argentine Precordillera: Geological Journal, v. 48, p. 256-269.

Chafetz, H.S., 1986, Marine peloids: a product of bacterially induced precipitation of calcite: Journal of Sedimentary Petrology, v. 56, p. 812-817.

Chafetz, H.S., and Guidry, S.A., 1999, Bacterial shrubs, crystal shrubs, and ray-crystal shrubs: bacterial vs. abiotic precipitation: Sedimentary Geology, v. 126 , p. $57-74$.

Chen, J., and Lee, J.H., 2014, Current progress on the geological record of microbialites and microbial carbonates: Acta Geologica Sinica, v. 88 , p. 260-275.

Choh, S.J., Hong, J., Sun, N., Kwon, S.W., Park, T.Y., Woo, J., Kwon, Y.K., Lee, D.C., and Lee, D.J., 2013, Early Ordovician reefs from the Taebaek Group, Korea: constituents, types, and geological implications: Association of Korean Geoscience Societies and Springer, Geosciences Journal, v. 17, p. $139-149$

Church, S.B., 1991, A new Lower Ordovician species of Calathium, and skeletal structure of western Utah calathids: Journal of Paleontology, v. 65 , p. 602-610.

Cuffey, R.J., Chuantao, X., Zhu, Z., Spjeldnaes, N., and Hu, Z.-X., 2013, The world's oldest-known bryozoan reefs: late Tremadocian, mid-Early Ordovician; Yichang, central China, in Ernst, A., Schäfer, P., and Scholz, J., eds. Bryozoan Studies 2010: : Berlin/Heidelberg, Springer-Verlag, p. 13-27.

Debrenne, F., Gangloff, R.A., and Lafuste, J., 1987, Tabulaconus Handfield: microstructure and its implication in the taxonomy of primitive corals: Journal of Paleontology, v. 61, p. 1-9.

Deng, Z.Q., 1984, Middle-Upper Ordovician corals from the marginal areas of the Ordos Platform, China: Bulletin of Nanjing Institute of Geology and Palaeontology, Chinese Academy of Sciences, v. 8, p. 305-322.

Elias, R.J., Lee, D.-J., and Woo, S.-K., 2008, Corallite increase and mural pores in Lichenaria (Tabulata, Ordovician): Journal of Paleontology, v. 82, p. $377-390$.

Fernandez-Martinez, E., Carrera, M.G., and Rodriguez, S., 2004, Corales tabulados del Ordovícico (Caradoc) de la Precordillera Argentina: Revista Española de Paleontología, v. 19, p. 47-59.

Flügel, E., 2004, Microfacies of Carbonate Rocks: Berlin, Springer-Verlag, 976 p.

Fuller, M.K., and Jenkins, R.F.J., 1994, Moorowipora chamberensis, a new coral from the early Cambrian Moorowie Formation, Flinders Ranges, South Australia: Transactions of the Royal Society of South Australia, v. 118, p. $227-235$.
Garwood, E., 1914, Some new rock-building organisms from the lower Carboniferous beds of Westmorland: Geological Magazine, decade 6, v. 1, p. 265-271. Gomez, F.J., and Astini, R.A., 2015, Sedimentology and sequence stratigraphy within a mixed (carbonate-siliciclastic) rift to passive margin transition: the early to middle Cambrian of the Argentine Precordillera: Sedimentary Geology, v. 316, p. 39-61.

Handfield, R.C., 1969, Early Cambrian coral-like fossils from the northern Cordillera of western Canada: Canadian Journal of Earth Sciences, v. 6, p. 782-785.

Hicks, M., 2006, A new genus of early Cambrian coral in Esmeralda County, southwestern Nevada: Journal of Paleontology, v. 80, p. 609-615.

Hill, D., 1981, Rugosa and Tabulata, in Teichert C., ed., Treatise on Invertebrate Paleontology, Pt. F, Coelenterata, Supplement 1: Boulder, CO and Lawrence, KS, Geological Society of America and University of Kansas Press, v. 2, p. F379-F762.

Hong, J., Cho, S.-H., Choh, S.-J., Woo, J., and Lee, D.-J., 2012, Middle Cambrian siliceous sponge-calcimicrobe buildups (Daegi Formation, Korea): metazoan buildup constituents in the aftermath of the early Cambrian extinction event: Sedimentary Geology, v. 253-254, p. 47-57.

Hong, J., Choh, S., and Lee, D.-J., 2015, Untangling intricate microbial-sponge frameworks: the contributions of sponges to Early Ordovician reefs: Sedimentary Geology, v. 318, p. 75-84.

Jell, J.S., 1984, Cambrian cnidarians with mineralized skeletons, in Oliver, W.A., Jr., Sando, W.J., Cairns, S.D., Coates, A.G., Macintyre, I.G., Bayer, F.M., and Sorauf, J.E., eds., Recent Advances in the Paleobiology and Geology of the Cnidaria: Palaeontographica Americana, v. 54, p. 105-109.

Keller, M., 1999, Argentine Precordillera: sedimentary and plate tectonic history of a Laurentian crustal fragment in South America: Geological Society America Special Paper, v. 341, 131 p.

Keller, M., 2012, The Argentine Precordillera: a little American carbonate bank, in Derby, J.R., Fritz, R.D., Longacre, S.A., Morgan, W.A., and Sternbach, C.A., eds., The Great American Carbonate Bank: The Geology and Economic Resources of the Cambrian-Ordovician Sauk Megasequence of Laurentia: AAPG Memoir, v. 98, p. 985-1000.

Keller, M., and Flügel, E., 1996, Early Ordovician reefs from Argentina: stromatoporoid vs. stromatolite origin: Facies, v. 34, p. 177-192.

Keller, M., Cañas, F.L., Lehnert, O., and Vaccari, N.E., 1994, The upper Cambrian and Lower Ordovician of the Precordillera (western Argentina): some stratigraphic reconsiderations: Newsletters in Stratigraphy, v. 31, p. $115-132$.

Kobluk, D., 1984, A new compound skeletal organism from the Rosella Formation (Lower Cambrian), Atan Group, Cassiar Mountains, British Columbia: Journal of Paleontology, v. 58, p. 703-708.

Kruse, P.D., and Reitner, J.R., 2014, Northern Australian microbial-metazoan reefs after the mid-Cambrian mass extinction: Memoirs of the Association of Australasian Palaeontologists, v. 45, p. 31-53.

Kruse, P.D., and Zhuravlev, A.Y., 2008, Middle-late Cambrian RankenellaGirvanella reefs of the Mila Formation, northern Iran: Canadian Journal of Earth Science, v. 45, p. 619-639.

Lafuste, L., Debrenne, F., Gandin, A., and Gravestock, D., 1991, The oldest tabulate coral and the associated Archaeocyatha, lower Cambrian, Flinders Ranges, South Australia: Geobios, v. 24, p. 697-718.

Lee, J.-H., Chen, J., and Chough, S.K., 2015, The middle-late Cambrian reef transition and related geological events: a review and new view: Earth-Science Reviews, v. 145, p. 66-84.

Lee, J.-H., Hong, J., Woo, J., Ho, J.-R., Lee, D.-J., and Choh, S.-J., 2016, Reefs in the early Paleozoic Taebaek Group, Korea: a review: Acta Geologica Sinica (English edition), v. 90, p. 352-367

Lee, M., Sun, N., Choh, S., and Lee, D., 2014, A new Middle Ordovician reef assemblage from north-central China and its palaeobiogeographical implications: Sedimentary Geology, v. 310, p. 30-40.

Lee, M., Park, H., Tien, N.V., Choh, S.-J., Elias, R.J., and Lee, D.-J., 2016 , A new species of Amsassia from the Ordovician of Korea and South China: paleobiological and paleogeographical significance: Acta Geologica Sinica (English Edition), v. 90, p. 796-806.

Lehnert, O., 1995, Ordovizische Conodonten aus der Präkordillere Westargentiniens: ihre Bedeutung für Stratigraphie und Paläogeographie: Erlanger geologische Abhandlungen, v. 125, p. 1-193.

Lehnert, O., and Keller, M., 1993, The conodont record of the Argentine Precordillera: problems and possibilities: Zentralblatt für Geologie und Paläontologie, v. 1993, p. 231-244.

Lehnert, O., Miller, J.F., and Repetski, J.E., 1997, Paleogeographic significance of Clavohamulus hintzei Miller (Conodonta) and other Ibexian conodonts in an early Paleozoic carbonate platform facies of the Argentine Precordillera: Geological Society of America Bulletin, v. 109, p. 429-443.

Li, Q., Li, Y., Wang, J., and Kiessling, W., 2015, Early Ordovician lithistid sponge-Calathium reefs on the Yangtze Platform and their paleoceanographic implications: Palaeogeography, Palaeoclimatology, Palaeoecology, v. 425 , p. $84-96$. 
Li, Q., Li, Y., and Kiessling, W., 2016, The oldest labechiid stromatoporoids from intraskeletal crypts in lithistid sponge-Calathium reefs: Lethaia, DOI: $10.1111 /$ let.12182.

Lin, B.Y., and Chow, X.H., 1980, Fossil corals from Middle Ordovician in Jiangshan, Zhejiang: Chinese Academy of Geological Sciences, Institute of Geology Journal, v. 1, p. 28-45.

Liu, B., Zhu, Z., and Li, X., 2005, A discussion on several problems of calathid fossils: Acta Palaeontologica Sinica, v. 44, p. 267-282. [in Chinese with English abstract]

Mángano, G., and Buatois, L., 2003, Trace fossils, in Benedetto, J.L., ed., Ordovician Fossils of Argentina: Córdoba, Secretaría de Ciencia y Tecnología, Universidad Nacional de Córdoba, p. 507-553.

Maslov, V.P., 1954, O nizhnem silure Vostochnoy Sibiri. in Voprosy geologii Azii I Moscow, USSR Academy of Sciences Publishing House, p. $495-531$

Miller, J.F., 1969, Conodont fauna of the Notch Peak Limestone (Cambro-Ordovician), 614 House Range, Utah: Journal of Paleontology, v. 43, p. 413-439.

Milne-Edwards, H., and Haime, J., 1850, A Monograph of the British Fossil Corals, Part1: London, Palaeontographical Society Monographs, p. 1-322.

Nicholson, H.A., and Etheridge, R. Jr., 1878, A Monograph of the Silurian Fossils of the Girvan District in Ayrshire with Special Reference to those Contained in the Gray Collection: v. 1, Fasciculus 1 (Rhizopoda, Actinozoa, Trilobita): Edinburgh, W. Blackwood and Sons, 135 p.

Pandolfi, J.M., 1989, Phylogenetic analysis of the early tabulate corals: Palaeontology, v. 32, p. 745-764

Popov, L.E., Cocks, L.R.M., and Nikitin, I.F., 2002, Upper Ordovician brachiopods from the Anderken Formation, Kazakhstan: their ecology and systematics: Bulletin of the Natural History Museum Geology Series, v. 58, p. $13-79$.

Pratt, B.R., 1984, Epiphyton and Renalcis-diagenetic microfossils from calcification of coccoid blue-green algae: Journal of Sedimentary Petrology, v. 54 , p. $948-971$.

Pratt, B.R., and James, N.P., 1982, Cryptalgal-metazoan bioherms of early Ordovician age in the St. George Group, western Newfoundland: Sedimentology, v. 29 , p. 543-569.

Pratt, B., Spincer, B., Wood, R., and Zhuravlev, A., 2001, Ecology and evolution of Cambrian reefs, in Zhuravlev, A.Y., and Riding, R., eds., The Ecology of the Cambrian Radiation: New York, Columbia University Press, p. 254-274.

Pratt, B.R., Raviolo, M.M., and Bordonaro, O.L., 2012, Carbonate platform dominated by peloidal sands: Lower Ordovician La Silla Formation of the eastern Precordillera, San Juan, Argentina: Sedimentology, v. 59, p. 843-866.

Rasetti, F., 1945, New upper Cambrian trilobites from the Lévis Conglomerate: Journal of Paleontology, v. 19, p. 462-478.

Raviolo, M.M., Bordonaro, O.L., and Pratt, B.R., 2007, Revisión estratigráfica y litofacial de la Formación La Silla (Ordovícico Inferior) en la Precordillera Oriental de San Juan, Argentina: Latin American Journal of Sedimentology and Basin Analysis, v. 14, p. 117-128.

Reitner, J., 1993, Modern cryptic microbialite/metazoan facies from Lizard Island (Great Barrier Reef, Australia): formation and concepts: Facies, v. 29 , p. $3-40$

Riding, R., 1991, Calcified Cyanobacteria, in Riding, R., ed., Calcareous Algae and Stromatolites: Berlin, Springer-Verlag, p. 55-87.

Riding, R., 2002, Structure and composition of organic reefs and carbonate mud mounds: concepts and categories: Earth-Science Reviews, v. 58, p. $163-231$.

Riding, R., and Fan, J., 2001, Ordovician calcified algae and cyanobacteria, northern Tarim Basin subsurface, China: Palaeontology, v. 44, p. 783-810.

Riding, R., and Tomas, S., 2006, Stromatolite reef crusts, Early Cretaceous, Spain: bacterial origin of in situ-precipitated peloid microspar?: Sedimentology, v. 53, p. 23-34.

Riding, R., and Zhuravlev, A.Y., 1995, Structure and diversity of oldest spongemicrobe reefs: lower Cambrian, Aldan River, Siberia: Geology, v. 23, p. 649-652.

Rodríguez, S., Carrera, M.G., and Fernández-Martínez, E., 2002, Corales de la transición siluro-devónico en la Precordillera Argentina: Ameghiniana, v. 39 , p. $479-489$

Rowland, S.M., and Shapiro, R.S., 2002, Reef patterns and environmental influences in the Cambrian and earliest Ordovician, in Kiessling, W. Flügel, E., and Golonka, J., eds., Phanerozoic Reef Patterns: SEPM Specia Publication, v. 72, p. 95-128.

Scrutton, C.T., 1979, Early fossil cnidarians, in House, M.R., ed., The Origin of Major Invertebrate Groups: London, Systematics Association, v. Special Volume 12, p. 161-207.

Scrutton, C.T., 1984, Origin and early evolution of tabulate corals, in Oliver, W.A., Jr., Sando, W.J., Cairns, S.D., Coates, A.G., Macintyre, I.G., Bayer, F.M., and
Sorauf, J.E., eds., Recent Advances in the Paleobiology and Geology of the Cnidaria: Palaeontographica Americana, v. 54, p. 110-118.

Scrutton, C.T., 1997, The Palaeozoic corals, I: origins and relationships: Yorkshire Geological Society Proceedings, v. 51, p. 177-208.

Scrutton, C., 1999, Palaeozoic corals: their evolution and palaeoecology: Geology Today, v. 15, p. 184-193.

Shapiro, R.S., and Rigby, J.K., 2004, First occurrence of an in situ anthaspidellid sponge in a dendrolite mound (upper Cambrian; Great Basin, USA): Journal of Paleontology, v. 78, p. 645-650. DOI: http://dx.doi.org/10.1666/00223360(2004)078 < 0645:FOOAIS > 2.0.CO;2

Shen, J.S., Yu, C., and Bao, J.N., 1997, A Late Devonian (Famennian) RenalcisEpiphyton reef at Zhaijiang, Guilin, South China: Facies, v. 37, p. 195-210.

Sokolov, B.S., and Mironova, N.V., 1959, O novom rode ordovikskikh korallov Zapadnoy Sibiri i Severnogo Kazakhstana: Akademiya Nauk SSSR, Doklady, v. 129 , p. $1150-1153$.

Stephens, N.P., and Sumner, D.Y., 2002, Renalcids as fossilized biofilm clusters: Palaios, v. 17, p. 225-236.

Sun, N., Elias, R.J., and Lee, D.-J., 2014, The biological affinity of Amsassia: new evidence from the Ordovician of North China: Palaeontology, v. 57, p. 1067-1089.

Sun, S.Q., and Wright, V.P., 1989, Peloidal fabrics in Upper Jurassic reefal limestones, Weald Basin, southern England: Sedimentary Geology, v. 65, p. $165-181$.

Thomas, W.A., and Astini, R.A., 1999, Simple-shear conjugate rift margins of the Argentine Precordillera and the Ouachita embayment of Laurentia: Geological Society of America Bulletin, v. 111, p. 1069-1079.

Thompson, C., Kah, L., Astini, R., Bowring, S., and Buchwaldt, R., 2012, Bentonite geochronology, marine geochemistry, and the Great Ordovician Biodiversification Event (GOBE): Palaeogeography, Palaeoclimatology, Palaeoecology, v. 321-322, p. 88-101.

Toomey, D.F., and Ham, W.E., 1967, Pulchrilamina, a new mound-building organism from the Lower Ordovician rocks of West Texas and southern Oklahoma: Journal of Paleontology, v. 41, p. 981-987.

Toomey, D.F., and Nitecki, M.H., 1979, Organic buildups in the Lower Ordovician (Canadian) of Texas and Oklahoma: Fieldiana, Geology, New Series, v. 2, 181 p.

Vaccari, N.E., 1994, Las faunas de trilobites de las sucesiones carbonáticas del Cámbrico tardío y Ordovícico temprano de la Precordillera Septentrional, República Argentina [Ph.D. thesis]: Córdoba, Universidad Nacional de Córdoba, $271 \mathrm{p}$

Wang, J., Deng, X., Wang, G., and Li, Y., 2012, Types and biotic successions of Ordovician reefs in China: Chinese Science Bulletin, v. 57, p. 1160-1168.

Webby, B.D., 2002, Patterns of Ordovician reef development, in Kiessling, W., Flügel, E., and Golonka, J., eds., Phanerozoic Reef Patterns: SEPM Special Publication, v. 72, p. 129-180.

Webby, B.D., Elias, R.J., Young, G.A., Neuman, B.E.E., and Kaljo, D., 2004, Corals, in Webby, B.D., Droser, M.L., Paris, F., and Percival, I., eds., The Great Ordovician Biodiversification Event: New York, Columbia University Press, p. 124-146.

Winchell, N.H., and Schuchert, C., 1895, Sponges, graptolites and corals from the Lower Silurian of Minnesota, in Lesquereux, L., Woodward, A., Thomas, B.W., Schuchert, C., Ulrich, E.O., and Winchell, N.H., eds., The Geology of Minnesota, v. 3, Part 1 of the Final Report: Paleontology: Minneapolis, Minnesota Geological and Natural History Survey, p. 55-95.

Woodward, S., 1830, A Synoptic Table of British Organic Remains: London and Norwich, Longman, Rees, Orme, Brown, and Green, $50 \mathrm{p}$.

Yang, S.W., Jin, C.T., and Zhou, X.Y., 1978, Subclass Tabulata, in Guizhou Stratigraphic and Paleontological Working Team, eds Atlas of Fossils in Southwestern China, Guizhou Region Volume 1, Cambrian-Devonian: Beijing, Geological Publishing House, p. 161-251.

Ye, J., Yang, Y.Y., Xu, A.D., Zheng, B.Y., Zuo, Z.F., Zhou, Y., Li, J.S., Li, Z.X., Song, G.C., Yong, Y.X., Zhang, B.R., and Zhang, J.S., 1995, Ordovician reefs in south-western margin Ordos Basin: Beijing, Geological Publishing House, $66 \mathrm{p}$.

Yu, C.M., 1962, Middle Silurian fossil corals of the northern Qilian Mountains. in Institute of Geology and Palaeontology, Chinese Academy of Sciences, Institute of Geology, Chinese Academy of Geological Sciences, and Beijing Institute of Geology, eds Geology of Qilian Mountains, v. 4: Beijing, Science Press, p. 13-109.

Zhen, Y.Y., and Pickett, J., 2008, Ordovician (early Darriwilian) conodonts and sponges from west of Parkes, central New South Wales: Proceedings of the Linnean Society of New South Wales, v. 129, p. 57-82.

Zhuravlev, A.Yu., Debrenne, F., and Lafuste, J., 1993, Early Cambrian microstructural diversification of Cnidaria: Courier Forschungsinstitut Senckenberg, v. 164, p. 365-372.

Accepted 18 September 2016 